neofilolog

Czasopismo Polskiego Towarzystwa Neofilologicznego

ISSN 1429-2173, elSSN 2545-3971, 2021, NR 57/2, 237-247

http://dx.doi.org/10.14746/n.2021.57.2.5

http://poltowneo.org/

Krystian Kamiński

Maria Curie-Skłodowska University https://orcid.org/0000-0001-6826-8052

krys.kami@gmail.com

\title{
Emergency online teaching during the global pandemic - a review of selected cases from intemational research to date
}

\begin{abstract}
At the beginning of 2020, educational systems around the world faced one of the greatest and most important challenges of the $21^{\text {st }}$ century. Due to the global pandemic and the need to introduce social distancing rules, it was decided to close schools and switch to modes of learning that do not require physical contact between learners and teachers. This decision was associated with numerous problems and difficulties in various areas of school life and the necessity to introduce new rules. More than a year after the introduction of the new learning reality, teachers and students around the world have managed to adapt. International researchers are trying to describe this new order by asking questions about what the school looks like in the time of the pandemic, how students are doing, and what strategies teachers have adopted. The article focuses on research on education and foreign language teaching conducted in 2020 in China, South Korea, Germany, and Poland. The findings to date are combined with a brief description of the educational situation in these countries. Finally, the first conclusions and recommendations are formulated that can be drawn on the basis of data collected by international researchers.
\end{abstract}

Keywords: learning during the pandemic, foreign language teaching, China, South Korea, Germany, Poland

Słowa kluczowe: nauka w pandemii, nauczanie języków obcych, Chiny, Korea Południowa, Niemcy, Polska 


\section{Introduction}

The first quarter of 2020 is certainly going to be remembered by many generations around the world for a long time. Restrictions, new safety rules, and changes in various areas of social life. The global pandemic changed almost all aspects of the functioning that were previously known to us. At first, no one wanted to believe that this was not just a temporary situation. Everyone hoped that we would return to normal life after the first lockdown. The truth, however, turned out to be different. As soon as we got used to the thought of the pandemic, we began to look for ways to adjust all areas of life to the socalled new normality.

These changes and adjustments also concerned education at all levels - from preschool to higher education. Teachers, educators, policy makers and, above all, students began to adapt school to the conditions of social distancing. This was the factor that directed education to new modes of learning that do not require physical contact between learners and teachers. These took various forms and used various tools. Never before had e-learning, remote learning, synchronous and asynchronous learning via the Internet been implemented on such a global scale. However, as this situation came as a surprise to everyone, therefore, some of the changes were made by trial and error. There were many ideas for dealing with the pandemic, which also applies to educational practices during the global lockdown. As this situation affected all countries in the world, this article focuses on gathering and discussing selected interesting cases and information from available research on foreign language education during the 2020 pandemic from China, South Korea, Germany, and Poland. In particular, emphasis is placed on such aspects as focus research areas, educational stages researched, and forms of education mentioned during the pandemic, tools used and advantages/possibilities mentioned as well as disadvantages/failures as seen by researchers.

\section{China - focus on teachers}

The first place to be affected by the new virus was China. It was from the first experiences of this country that the whole world learned about SARS-CoV-2 (Peters et al., 2020). Fighting the constantly spreading virus, China introduced strict home quarantine and physical distancing rules. All educational institutions were temporarily closed, and the Chinese M inistry of Education introduced learning via the Internet. Learners from universities were encouraged to participate and jointly implement online learning and self-study using educational materials available on the Internet (Gao, Zhang, 2020). 
The intention in China was for online classes to be of the same quality as previous face-to-face classes. This required rapid devising and introduction of new teaching methods and management by teachers (Peters et al., 2020). A multi-dimensional evaluation of student achievement on the Internet was also recommended (Zhu, Liu, 2020). As a result, in the first months of the pandemic in China, 24,000 online courses were created for higher education institutions to provide flexible online learning to over 270 million students (Wang, 2020).

Distance learning research in China focused primarily on teachers - researching their digital skills, how they conducted remote teaching activities, managed and supervised online classes, and evaluated learning outcomes (Zhu, Liu, 2020). In their qualitative study, Gao and Zhang (2020) held in-depth interviews with three EFL teachers from a Chinese university. The researchers wanted to find answers to questions concerning teachers' cognitions about online learning and their ICT literacy in the initial stage of COVID-19. Interviews with foreign language academics conducted by Gao and Zhang (2020) show that the teachers displayed extensive knowledge of the features, advantages, and limitations of online learning. The interviewees pointed to the unique merits of online EFL courses, including the possibility for teachers to keep track of learners' progress and provide immediate help, the unlimited availability of training materials for learners, and the new, interactive, and thus more engaging, forms of work. As for advantages, they mentioned the difference in the online learning needs of learners, parents, and schools, the lack of immediate contact between teachers and learners, and technical difficulties connected with hardware facilities and wi-fi conditions. The respondents developed their information and communications technology (ICT) skills for remote learning during the pandemic through "autonomous learning and exploration of relevant elements and technological skills" (Gao, Zhang, 2020: 9). The teachers tried to adjust their working methods to the students. This was possible thanks to feedback received in the form of questionnaires, assessed tests and information from class monitors. It was found that understanding of the educational needs of students and a skilful combination of traditional and modern methods, as well as the adaptation of previously used techniques, contributed to the success of online education. The research presents the key role played by teachers in ensuring efficient online learning, accessible to all, and meeting the highest criteria for quality. "They [teachers] are expected to have knowledge, skills, and ethics to conduct online teaching, and that calls for more flexible and dynamic post-pandemic teacher education" (Zhu, Liu, 2020: 698). 


\section{South Korea - cooperation of teachers in a system prepared for remote learning}

The outbreak of the pandemic in South Korea coincided with the beginning of the new school year in M arch 2020, therefore the Korean M inistry of Education decided to postpone it till April 2020 and finally to move online (Yoon, 2020). However, functioning online schooling is not a new situation for most learners and teachers since programmes aimed at making the Korean education system more technology-friendly had been implemented long before the pandemic crisis (Ministry of Education Republic of Korea, 2020). Of course, in the beginning, implementation of remote learning varied from school to school (Yoon, 2020), because it was the first time in history that the whole educational system was transferred online (M inistry of Education Republic of Korea, 2020)

One of the tools developed by the government for remote teaching in South Korea was the educational portal Edunet (www.edunet.net) that allows learners to watch lectures and submit their homework (Yoon, 2020). South Korean learners could also use a public educational network called the Educational Broadcasting System (EBS) with various educational programmes and an e-learning component similar to Google Classroom (Yi, Jang, 2020). "M ost public schools follow a national curriculum using state-issued textbooks, meaning the government's public education broadcaster can create and upload videos for daily lessons that serve a wide swathe of students" (Yoon, 2020). Teachers in South Korea were also advised to use other online tools, apps and resources such as YouTube, PowerPoint, and instant messaging apps (Yi, Jang, 2020) to present learning content and assignments, give learners feedback as well as to create conditions as similar to regular learning as possible both during asynchronous classes and lessons in real time (M inistry of Education Republic of Korea, 2020).

One of the latest pieces of research on FL remote teaching in South Korea was conducted by Yi and J ang (2020). A case study of two English language teachers from rural elementary school describes their collaboration as they created video lessons for their primary school learners. While the educator from Korea prepared the vocabulary and topics of the lessons, the native speaker teacher selected appropriate stories and contexts. The teachers carefully planned the use of the languages (English and Korean) in the films to ensure the greatest educational value for their learners. Because of this close collaboration, both teachers "had more opportunities to negotiate their teaching philosophies and methods and to reflect on their online materials and instruction during remote teaching" (Yi, Jang, 2020: 3). As a result, the lessons were betterstructured and more language-focused, which positively influenced learners' 
Emergency online teaching during the global pandemic - a review of selected...

perception and improved their linguistic skills. One of the advantages mentioned in the study is that the work on the videos deeply involved both teachers, their cooperation deepened, and they became equal and productive partners.

\section{Germany - the strength lies in the approach}

The quality of language education in the German school system is regarded as the highest among European countries (Thaler, 2017). For many years, the country has applied a policy of exposure to foreign languages and culture from the earliest stages of education. This means that all over Germany, children between the ages of 6 and 9 start learning a second foreign language (Sopata, 2010). According to Mindt and Schlüter (2003), the most important goal of early foreign language teaching in Germany should be achieving elementary communicative competence in a foreign language. Germans promote a "holistic approach to FL learning, primacy of oral skills and high tolerance to errors" (Sopata, 2010: 29).

During the onset of the COVID-19 pandemic, in spring 2020, German primary schools were closed for 7 weeks (Isphording, Lipfert, Pestel, 2021). As a result, English lessons were not held at that time because the emphasis was placed on developing core subjects, such as German and mathematics. Hopp and Thoma (2020) examined the impact of the closure of primary schools in Germany on the development of foreign languages (FL) in the early stages of foreign language education. Their study compares the language development of two groups of fourth grade learners from primary schools in Lower Saxony - 128 learners who were educated in the 2018/2019 school year without disruptions in the functioning of their schools and 141 learners who faced 15 weeks of suspension of foreign language classes in the 2019/2020 school year, due to the school closings caused by the pandemic. Researchers used the Test for Reception of Grammar to assess grammar and the British Picture and Vocabulary Scale for receptive vocabulary skills.

Hopp and Thoma (2020: 3) report that "temporary suspensions of FL teaching do not necessarily have detrimental effects on students' general FL development, even though no or only little compensatory FL instruction took place during the school shutdowns", therefore it is claimed that in the case of students at early stages of foreign language learning, the development of language skills is not hampered by a temporary break in contact with a foreign language in school settings. This may be related to the specific approach to early foreign language teaching in Germany, which is play- and action-oriented (Sopata, 2010) and focused on "awakening children's motivation to learn and creating the basis for maintaining high level of motivation" (Mindt, Schlüter, 2003: 17). 


\section{Poland - relationships are the most important}

The decision to close schools in Poland, as in other countries around the world, was taken suddenly and unexpectedly. Almost overnight, all participants of the educational process, regardless of the subject and level of education, were faced with the need to adapt to the new reality - without any guidelines or a top-down action plan (Deczewska, 2020). In some schools, the first attempts to introduce remote learning appeared shortly after the decision to close schools - even before the Polish Ministry of National Education directive on compulsory remote learning. In the first phase, remote learning in Poland took the form of e-learning, during which teachers sent learners instructions and tasks via platforms such as MS Teams, Google Classroom, e-mail or online gradebook (Karolczuk, 2020). In the 2020/2021 school year, most classes took place in a synchronous mode with the use of conference platforms such as MS Teams, Google M eet, Zoom or Skype and online tools, including Kahoot, Quizziz, LearningApps and the like (Buchner, Wierzbicka, 2020; Ptaszek et al., 2020).

The situation of all participants of the learning process (students and teachers, as well as their families) has been described in studies on various aspects of remote teaching (Buchner, W ierzbicka, 2020; Jaskulska, Jankowiak, 2020; Karolczuk, 2020; Ptaszek et al., 2020). These were based on surveys which used online tools to collect the answers, containing both open-ended and closed-ended questions. Among the respondents there were teachers from different types of Polish schools (primary school-vocational school), with different professional experience (trainee teachers-certified teachers), from various cities in Poland. It was extensive research focused on examining many aspects of distance learning - from the work techniques applied to aspects concerning the psychological state of the respondents.

As regards technical aspects, difficulties reported were related to internet connections (Buchner, Wierzbicka, 2020), availability of computers and devices (Ptaszek et al., 2020), the ability to use distance learning technology (Buchner, Wierzbicka, 2020), organisation of home life and adapting to online learning (Karolczuk, 2020). However, the area that caused the most difficulties were relationships. Jaskulska and Jankowiak (2020: 66) claim that during the pandemic school was "reduced to a didactic function". Research shows that the mental well-being of students, teachers and parents during the pandemic was worse compared to the time before the pandemic (Buchner, Wierzbicka, 2020; Ptaszek et al., 2020). The school in the pandemic should, therefore, shift its main goals of online learning from education to being a place for nurturing relationships, a platform for contact between peers and teachers. In offline conditions, this aspect is naturally fulfilled through direct social contact. 
Emergency online teaching during the global pandemic - a review of selected...

The aspect of teaching foreign languages during the pandemic is discussed, among others, by Karolczuk (2020) and Krajka (2021). Surveys and interviews conducted with FL teachers, students and parents shed light on language classes during the pandemic. FL classes were usually held in a synchronous mode. FL teachers also used Google Drive, Google Classroom, and the Moodle platform to post tasks and didactic materials (Karolczuk, 2020) as well as websites such as Padlet, Wordwall, islcollective.com, and Quizziz (Krajka, 2021). A problem experienced by all teachers was the reluctance of students to turn cameras on during online meetings, which made the class less engaging for students and more exhausting for teachers (Buchner, Wierzbicka, 2020). Karolczuk (2020: 41) claims that "for the most part, both teachers and students had the impression that the effectiveness of remote FL learning was lower than the traditional one". Interesting information comes from the interviews in the study by Krajka (2021), showing that it was easiest for teachers to teach online in a way that was as close as possible to teaching in the classroom. Therefore, they tried to "set up pair/group work activities in breakout rooms or vocabulary/grammar presentations, mindmaps or vocabulary brainstorming through screen sharing" (p. 125).

\section{Discussion}

The changes initiated by the COVID-19 crisis may reshape the image of modern education. Scholars from all over the world are trying to describe the influence of the introduction of modes of teaching altered for social distancing. Table 1 presents information on the international research on distance learning described in this article. The phenomena mentioned cannot be clearly criticised or praised due to the inability to assess their future didactic impact. Research is still ongoing, and the development of the global pandemic will affect its direction.

The long-term effects of remote learning during the pandemic are not yet known and are difficult to predict. We can only guess what effect such a massive change will have on teachers and learners. The success of distance learning depends not only on participants of the education system, but, as the German research shows, also on the very structure of the system and approaches to teaching as such. A holistic approach and strengthening positive motivation to learn FL in learners from an early age allowed students in the German study to develop skills even in conditions of limited access to classes.

Changing the teaching mode and immediate adaptation to new online conditions is a huge challenge for both learners and teachers. Technical difficulties are, however, a factor that can be easily dealt with institutionally. The Korean research shows that by having the right technical tools to work remotely, teachers were able to focus on adapting and improving their working 
methods so that the remote learning process brought even more benefits to learners. By reacting to the new reality and solving the problems that arose, the teachers created new solutions that can be used at schools and that bring innovation to their daily practice.

\begin{tabular}{|c|c|c|c|c|}
\hline & China & South Korea & Germany & Poland \\
\hline $\begin{array}{l}\text { focus research } \\
\text { area(s) }\end{array}$ & $\begin{array}{l}\text { foreign language } \\
\text { teachers' cognitions } \\
\text { about online teaching }\end{array}$ & $\begin{array}{l}\text { case study of collab- } \\
\text { orative teaching } \\
\text { practices }\end{array}$ & $\begin{array}{l}\text { impact of the clo- } \\
\text { sure of schools on } \\
\text { the development of } \\
\text { foreign languages }\end{array}$ & $\begin{array}{l}\text { situation of all par- } \\
\text { ticipants of the } \\
\text { learning process }\end{array}$ \\
\hline $\begin{array}{l}\text { educational } \\
\text { stage(s) } \\
\text { researched } \\
\end{array}$ & academic & primary & primary & primary-vocational \\
\hline $\begin{array}{l}\text { forms of education } \\
\text { during pandemic } \\
\text { mentioned and } \\
\text { tools } \\
\text { implemented }\end{array}$ & $\begin{array}{l}\text { combination of syn- } \\
\text { chronous and indi- } \\
\text { vidual sections } \\
\text { within one lesson; } \\
\text { online platforms: } \\
\text { Ping Talk, Chaoxing, } \\
\text { M OOC, Baidu Disk; } \\
\text { social networking } \\
\text { apps: WeChat, QQ; } \\
\text { PDF versions of text- } \\
\text { books; }\end{array}$ & $\begin{array}{l}\text { synchronous and } \\
\text { asynchronous clas- } \\
\text { ses (depending on } \\
\text { educator); } \\
\text { Educational Broad- } \\
\text { casting Services - } \\
\text { TV and radio net- } \\
\text { work as well as e- } \\
\text { learning platform; } \\
\text { instant messaging } \\
\text { apps; }\end{array}$ & $\begin{array}{l}\text { focus on developing } \\
\text { core subjects, such } \\
\text { as German and } \\
\text { mathematics; } \\
\text { no regular foreign } \\
\text { language classes for } \\
\text { at least } 7 \text { weeks; }\end{array}$ & $\begin{array}{l}\text { synchronous and asyn- } \\
\text { chronous classes (de- } \\
\text { pending on phase); } \\
\text { online platforms: MS } \\
\text { Teams, Google Class- } \\
\text { room; } \\
\text { conference tools: } \\
\text { MS Teams, Google } \\
\text { M eet, Zoom, Skype; } \\
\text { online tools: Kahoot, } \\
\text { Quizziz, Learn- } \\
\text { ingApps; }\end{array}$ \\
\hline
\end{tabular}

Table 1: Information gathered from research included in the article.

The research of Chinese scientists emphasises the role of highly qualified pedagogical staff who are responsible for the preparation and implementation of remote learning. M oreover, the remote learning experience, especially the need to use ICT tools during e-learning, may lead them to use more educational applications and computer tools in class when they return to the offline learning mode.

The Polish research confirms what was stated in the independent report "Thinking about Pedagogy in an Unfolding Pandemic" published in March 2020, at the very beginning of distance learning. Its authors (Doucet, Netolicky, Timmers \& Tuscoano, 2020) proclaimed that one of the main assumptions of education during the pandemic should be "Maslow before Bloom". This means that before we expect to achieve educational goals, we must ensure the safety of students and teachers and meet other more basic needs, including those related to relationships.

\section{Conclusion}

This article focused on the presentation of the nature of emergency online teaching on the basis of selected studies available. Due to the interventional 
nature of changes in teaching and the continuing spread of the pandemic, the situation in school systems is developing day by day and both students and teachers are constantly adapting to it. Further studies on the described aspects are also carried out, as the pandemic situation in schools is constantly changing. It should, therefore, be emphasised that this article, written in mid2021, refers to research on the situation from the beginning of the pandemic.

One of the most important conclusions from the research conducted so far seems to be the need to build relationships and provide care for the emotional and psychological well-being of students in the period of lockdown and social distancing. The training of future teachers will also have to be changed. University teacher training programmes should be updated to include practical information on remote teaching. Teachers al ready working in the profession should also receive help with e-learning tools even after returning to lessons in schools.

\section{BIBLIOGRAPHY}

Buchner A., Wierzbicka M. (2020). Edukacja zdalna w czasie pandemii. Edycja II. Warszawa: Centrum Cyfrowe. Online: https://centrumcyfrowe.pl/wp -content/uploads/sites/16/2020/11/Raport_Edukacja-zdalna-w-czasie-p andemii.-Edycja-II.pdf [access date: 03.05.2021].

Deczewska J . (2020). Interakcje między uczestnikami nauczania zdalnego - wyzwania, oczekiwania, możliwe rozwiq̨zania. "Języki Obce w Szkole", 3 (2020), pp. 13-18.

Doucet A., Netolicky D., Timmers K., Tuscano F.J. (2020). Thinking about Pedagogy in an Unfolding Pandemic, An Independent Report on Approaches to Distance Learning During COVID19 School Closures. Online: https:// issuu.com/educationinternational/docs/2020_research_covid-1 9_eng [access date: 13.05.2020].

Gao L.X, Zhang L.J. (2020). Teacher Learning in Difficult Times: Examining Foreign Language Teachers' Cognitions About Online Teaching to Tide Over COVID19. "Frontiers in Psychology", 11, 549653.

Hopp H., Thoma D. (2020). Foreign Language Development During Temporary School Closures in the 2020 Covid-19 Pandemic. "Frontiers in Education", 5, 601017.

Isphording I. E., Lipfert M., Pestel N. (2021). Does re-opening schools contribute to the spread of SARS-CoV-2? Evidence from staggered summer breaks in Germany. "Journal of Public Economics", 198, 104426.

Jaskulska S., Jankowiak B. (2020). Jaki obraz szkoły w czasie pandemii COVID-19 wyłania się z badań nauczycieli i uczniów? Wnioski dla bliższej i dalszej przyszłości, (in:) Pikuła N.G., Jagielska K., Łukasik J.M. (eds.), Wyzwania 
dla edukacji w sytuacji pandemii COVID-19. Kraków: Wydawnictwo «scriptum», pp. 57-70.

Karolczuk M . (2020). Zdalnie realnie. Jak uczymy (się) języków w czasie pandemii. "J ęzyki Obce w Szkole", 2(2020), pp. 39-43.

Krajka J. (2021). Teaching grammar and vocabulary in COVID-19 times: Approaches used in online teaching in Polish schools during a pandemic. "The JALT CALLJournal", 17 (2), pp. 112-134.

M indt D., Schlüter N. (2003). Englisch in den Klassen 3 und 4. Grundlagen für einen ergebnisorientierten Unterricht. Berlin: Cornelsen.

Ministry of Education Republic of Korea. (2020). Responding to Covid-19: Online Classes in Korea - A Challenge Toward the Future of Education. Sejong. Online: https://www.mofa.go.kr/\%2Feng\%2Fbrd\%2Fm_227 47\%2Fdown.do\%3Fbrd_id\%3D20548\%26seq\%3D3\%26data_tp\%3DA\% 26file seq\%3D1\&usg=AOVVaw0M pOdM 7-gm7mpbFWiCeWmm [access date: 10.05 .2021$]$.

Peters M.A., Wang H., Ogunniran M.O., Huang Y., Green B., Chunga J.O., Quainoo E.A., Ren Z., Hollings S., M ou C., Khomera S.W., Zhang M ., Zhou S., Laimeche A., Zheng W., Xu R., Jackson L., Hayes S. (2020). China's Internationalized Higher Education During Covid-19: Collective Student Autoethnography. "Postdigital Science and Education", 2, pp. 968-988. Ptaszek G., Stunża G.D., Pyżalski J., Dębski M. ., Bigaj M . (2020). Edukacja zdalna: co stało się z uczniami, ich rodzicami i nauczycielami? Gdańsk: Gdańskie Wydawnictwo Psychologiczne.

Sopata A. (2010). Wczesnoszkolna edukacja językowa w Niemczech. "Poliglota. Edukacja językowa dzieci", 1 (11), pp. 18-28.

Thaler E. (2017). English and foreign language teaching in the German Gymnasium. "Training, Language and Culture", 1 (3), pp. 72-85.

Wang Y. (2020). How does the Chinese education system cope with the virus outbreak challenge?. "China Daily". Online: https://news.cgtn.com/ne ws/2020-02-18/China-s-online-learning-sector-thrives-amid-epidemicObnQfU8hfW/index.html [access date: 06.05.2020].

Yi Y., Jang J. (2020). Envisioning possibilities amid the COVID-19 pandemic: Implications from English language teaching in South Korea. "TESOL J ournal", 11 (3), e543.

Yoon D. (2020). South Korea's Coronavirus Lesson: School's Out for a While. "The Wall Street Journal". Online: https:// www.wsj.com/articles/ remot e-learning-in-south-korea-becomes-a-fixture-of-pandemic-life-115996 68494 [access date: 08.05.2021]. 
Emergency online teaching during the global pandemic - a review of selected...

Zhu X., Liu J. (2020). Education in and After Covid-19: Immediate Responses and Long-Term Visions. "Postdigital Science and Education", 2, pp. 695-699.

Received: 15.05.2021

Revised: 28.08.2021 